\title{
Nedocromil Sodium Inhibits Bradykinin- and Antigen-induced Plasma Extravasation in Guinea Pig Airways
}

Shigemi Yoshihara, Mika Ono, Yumi Yamada, Norimasa Fukuda, Toshio Abe and Osamu Arisaka Department of Pediatrics, Dokkyo University School of Medicine, 880 Kitakobayashi, Mibu-machi, Shimotsuga-gun, Tochigi, 321-0293, JAPAN

(Received 21 January 2001; and accepted 7 February 2001)

\begin{abstract}
This study was designed to investigate the inhibitory effect of Nedocromil sodium (NS) on bradykinin- and antigen-induced plasma extravasation in guinea pig trachea. Plasma extravasation was assessed by photometric measurement of extravasated Evans blue dye after formamide extraction. Pretreatment with NS $(0.1,1$, and $10 \mathrm{mg} / \mathrm{kg}$ i.v.) significantly and dose-dependently reduced bradykinin (inhalation, $0.1 \mathrm{mM}, 2 \mathrm{~min}$ )-induced plasma extravasation in the presence of neutral endopeptidase inhibitor, phosphoramidon $(2.5 \mathrm{mg} / \mathrm{kg}$ i.v. $)$, in the trachea. Pretreatment with NS (10 mg/kg i.v.) or disodium cromoglycate (DSCG; $10 \mathrm{mg} /$ $\mathrm{kg} i$.v.) significantly reduced antigen-induced (inhalation of ovalbumin; $5 \%, 2 \mathrm{~min}$ ) plasma extravasation in the sensitized guinea pig trachea. Inhibition of the antigen-induced plasma extavasation in the trachea by NS $(10 \mathrm{mg} / \mathrm{kg} i . v$.) was significantly greater than the inhibition by DSCG $(10 \mathrm{mg} / \mathrm{kg} i . v$.) and similar to the inhibition by pretreatment with a combination of NS and FK224. Pretreatment with the combination of NS and antihistaminic drugs inhibited the antigen-induced plasma extavasation in the trachea more than the antihistaminic drugs alone. However, the inhibition by pretreatment with the combination of NS and antihistaminic drugs did not differ from the inhibition by NS alone. These findings suggest that NS inhibits antigen-induced plasma extravasation, histamine release by mast cells and tachykinin release from sensory nerves activated from bradykinin stimulation in sensitized guinea pig airway.
\end{abstract}

Asthma is a chronic inflammatory disease characterized by eosinophil and lymphocyte infiltration and epithelial shedding (10) in the airway. There is increasing evidence that the sensory nerves of the airway play a role in the asthmatic response. Nerve endings are exposed by the epithelial shedding associated with asthma, and they may become sensitized and activated by inflammatory mediators and release neuropeptides that

Correspondence to: Dr Shigemi Yoshihara, at above address.

Tel: $+81-282-87-2155$

Fax: +81-282-86-7521

Email: shigemi@dokkyomed.ac.jp then spread and amplify the inflammatory process throughout the airway $(3,15)$.

Disodium cromoglycate (DSCG) was the first prophylactic non-steroidal drug licensed for the treatment of chronic asthma. It is a derivative of chromone-2-carboxylic acid and has a flexible hydrophilic structure with a bicyclic ring system. Nedocromil sodium (NS) is a new pyranoquinoline dicarboxylic acid derivative developed to manage reversible airflow obstruction. NS, but not DSCG, reduces antigen-induced plasma extravasation in guinea pig nasal mucosa (8). The combination of NS and the $\mathrm{NK}_{1}$ receptor antagonist CP-99,994 did not augment the inhibition caused by NS alone (8). NS also reduces the 
early-phase reaction of the allergic response as effectively as DSCG in a guinea pig model of ocular anaphylaxis (6), and NS has been found to be at least one order of magnitude more potent than DSCG in suppressing histamine release from mast cells (9). Since NS alone had only a small effect on leakage directly induced by histamine and platelet activating factor (PAF), its effect is probably due to inhibition of mediator release from inflammatory cells (presumably mast cells) (2). NS may have effects on sensory nerve endings, which may be an important site of action in the reduction of both neurogenic inflammation in airways and the symptoms of asthma, including cough(2), although the mechanism of action is not clear.

The specific aim of the present study was threefold: first, to determine whether NS inhibits bradykinin-induced plasma extravasation in guinea pig trachea and to compare it with DSCG; second, to determine whether NS inhibits antigeninduced plasma extravasation in sensitized guinea pig airway and to compare it with DSCG and the combination of $\mathrm{NS}$ and $\mathrm{NK}_{1}$ and $\mathrm{NK}_{2}$ receptor antagonist FK224, and third, to determine whether NS inhibits antigen-induced plasma extravasation in response to antigen in sensitized guinea pig airway and compare it with antihistaminic drugs and the combination of NS and antihistaminic drugs.

\section{MATERIALS AND METHODS}

\section{Animals}

Male Hartley guinea pigs (Japan SLC, Inc.), weighing $300-500 \mathrm{~g}$ at the time of housing, were used in this study. They were kept in a temperature controlled environment with standard laboratory food and water freely available.

\section{Sensitization procedure}

The animals were sensitized according to a protocol described previously (14) that consisted of injection of $70 \mathrm{mg}$ ovalbumin (Grade V) in 1.5 $\mathrm{mL} 0.9 \% \mathrm{NaCl}$ intraperitoneally twice with a one week interval between injections. The animals were studied two weeks after the second injection.

\section{Experimental design}

On the day of the experiment, the guinea pigs $(300-500 \mathrm{~g})$ were anesthetized with sodium pentobarbital $(50 \mathrm{mg} / \mathrm{kg}$ i.p. $)$. A midline cervical incision was made to expose the larynx and upper trachea. The trachea was incised immediately below the larynx, and a cannula was inserted 4 $\mathrm{mm}$ into the trachea. The animals were then artificially ventilated at a frequency of 70 breaths/min with a tidal volume of $6 \mathrm{~mL}$ using a constant volume ventilator (Rodent Ventilator Model 683, Harvard Apparatus, Millis, MA, U.S. A.). Neutral endopeptidase inhibitor, phosphoramidon $(2.5 \mathrm{mg} / \mathrm{kg} i . v$.), dissolved in $0.9 \% \mathrm{NaCl}$ was injected into the jugular vein over a $10 \mathrm{~s}$ period $5 \mathrm{~min}$ before the inhalation. We used Evans blue dye ( $3 \%$ solution in $0.9 \% \mathrm{NaCl}$ ) to measure plasma extravasation. Immediately after the injection of the dye $(30 \mathrm{mg} / \mathrm{kg} i . v$. over $5 \mathrm{~s})$ in the jugular vein, bradykinin $(0.1 \mathrm{mM})$ or ovalbumin (OVA; 5\%) aerosol was delivered to animals for 2 min via the tracheal cannula, using an ultrasonic nebulizer (Pulmo-Sonic model 25, De Vilbiss Co., Somerset, PA; aerosol delivery rate $0.2 \mathrm{~mL} / \mathrm{min}$ ). The vehicle of bradykinin and OVA was $0.9 \% \mathrm{NaCl}$. Nedocromil sodium (NS; $0.1,1$ and $10 \mathrm{mg} / \mathrm{kg} i . v$.), disodium cromoglycate (DSCG; $10 \mathrm{mg} / \mathrm{kg}$ i.v.) or vehicle was injected 5 min before the stimulus. The combination of NS $(10 \mathrm{mg} / \mathrm{kg}$ i.v.) and FK224 (3.2 mg/kg i.v.) or vehicle was given $10 \mathrm{~min}$ before the stimulus. The $\mathrm{H}_{1}$ and $\mathrm{H}_{2}$ receptor antagonists pyrilamine $(10 \mathrm{mg} / \mathrm{kg}$ i.v.) and cimetidine (10 mg/ $/ \mathrm{kg} i . v$ ), respectively, or the combination of NS $(10 \mathrm{mg} / \mathrm{kg}$ i.v.) and antihistaminic drugs (pyrilamine and cimetidine; $10 \mathrm{mg} / \mathrm{kg} i . v$. each) were administered 30 min before the stimulus. NS, DSCG, pyrilamine, and cimetidine were dissolved in saline; FK224 was dissolved in dimethylsulfoxide (DMSO). The chest was opened $10 \mathrm{~min}$ after injection of the tracer, a cannula was inserted into the ascending aorta through the left ventricle, and the circulation was perfused for 3 min with a 10 $\mathrm{mM}$ phosphate buffer of $\mathrm{pH} 5$ at a pressure of 120 $\mathrm{mmHg}$. The trachea were then removed, opened longitudinally along the ventral midline, blotted on bibulous paper, and weighed. Tissue was incubated in $3 \mathrm{~mL}$ of formamide at $50^{\circ} \mathrm{C}$ for $18 \mathrm{~h}$ to a extract the extravasated Evans blue dye. The results were compared with those obtained from animals not treated with NS or DSCG.

\section{Measurement of plasma extravasation}

Extravasation of the dye-labeled macromolecules was assessed by measuring the optical density of 
the formamide extracts at a wavelength of $620 \mathrm{~nm}$ with a spectrophotometer (model 220A, Hitachi, Japan). The amount of Evans blue dye extravasated from the tissue, expressed in $\mathrm{ng} / \mathrm{mg}$ of wet weight, was interpolated from a standard curve of Evans blue dye concentrations.

\section{Drugs}

Bradykinin and phosphoramidon were purchased from Peptide Institute Inc (Osaka, Japan). NS was kindly provided by Dr. A. Norris (RhonnePoulenc Rorer, PA, USA). FK224 and DSCG were supplied by Fujisawa Pharmaceutical Co. Ltd.(Tokyo, Japan). Ovalbumin, Evans blue dye, pyrilamine, and DMSO were obtained from Sigma Chemical Co. (St. Louis, MO, USA). Cimetidien was purchased from SmithKline Beecham (Tokyo, Japan).

\section{Statistical analysis}

All data are expressed as means \pm s.E.M. Statistical comparisons were performed using a one-way analysis of variance and Dunnett's test or bilateral unpaired Students $t$-test, when appropriate. In all cases, a $P$ value of less than 0.05 was considered significant.

\section{RESULTS}

\section{Effect of NS and DSCG on bradykinin-induced plasma extravasation}

Extravasation of Evans blue dye in the guinea pig trachea after exposure to aerosolized vehicle of bradykinin in the presence of phosphoramidon $(2.5 \mathrm{mg} / \mathrm{kg}$, i. v.) was $33.3 \pm 5.8 \mathrm{ng} / \mathrm{mg}(\mathrm{n}=5$; Fig. 1). Injection of the vehicle for bradykinin $(0.9 \% \mathrm{NaCl})$ did not affect baseline plasma extravasation (data not shown). Inhalation of 0.1 $\mathrm{mM}$ bradykinin for $2 \mathrm{~min}$ in the presence of phosphoramidon $(2.5 \mathrm{mg} / \mathrm{kg}, \quad i . v$. $)$ significantly increased the extravasation of Evans blue dye in the trachea ( $97.9 \pm 7.9 \mathrm{ng} / \mathrm{mg}, \mathrm{n}=5$; Fig. 1). Pretreatment with DSCG $(10 \mathrm{mg} / \mathrm{kg} i . v$. $) 5 \mathrm{~min}$ before aerosol challenge significantly reduced the plasma extavasation in the trachea $(60.8 \pm 5.8$ $\mathrm{ng} / \mathrm{mg}, \mathrm{n}=5$; Fig. 1). Pretreatment with NS (0.1, 1 , and $10 \mathrm{mg} / \mathrm{kg}$ i.v.) $5 \mathrm{~min}$ before aerosol challenge significantly and dose-dependently reduced the bradykinin-induced plasma extravasation in the trachea $(60.5 \pm 5.5,52.9 \pm 3.1$, and $38.9 \pm$ $3.4 \mathrm{ng} / \mathrm{mg}, P<0.05, \mathrm{n}=5$ each; Fig. 1). The inhi-

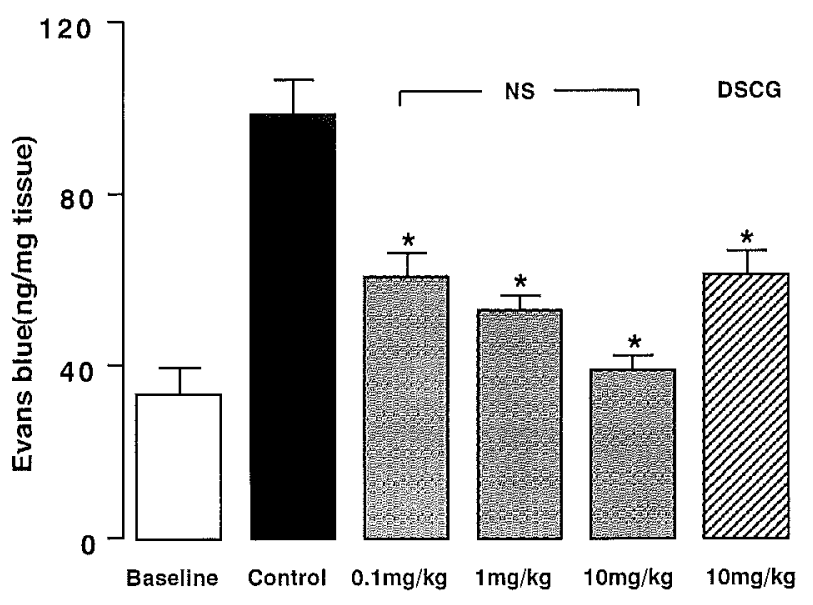

Fig. 1 Effect of nedocromil sodium $(0.1,1$ and 10 $\mathrm{mg} / \mathrm{kg} i . v)$ or disodium cromoglycate $(10 \mathrm{mg} / \mathrm{kg} i . v$.) on Evans blue extravasation in guinea pig trachea induced by inhalation of bradykinin $(0.1 \mathrm{mM}, 2 \mathrm{~min})$ in presence of phosphoramidon $(2.5 \mathrm{mg} / \mathrm{kg}$ i.., 5 min before exposure). Plasma extravasation was evaluated by measuring the amount of Evans blue dye extravasated in the trachea after $10 \mathrm{~min}$. Values are means \pm S.E.M; $n=5$ per group. ${ }^{*} P<0.05$ versus control (Inhalation of bradykinin in presence of phosphoramidon) in trachea.

bition of bradykinin-induced plasma extravasation caused by NS ( $10 \mathrm{mg} / \mathrm{kg} i . v$.) was similar to the baseline value, but the inhibition caused by DSCG $(10 \mathrm{mg} / \mathrm{kg} i . v$. $)$ was less prominent as compared with the NS administration. The NS and DSCG vehicle had no effect on the bradykinin-induced plasma extravasation (data not shown).

Effect of NS, DSCG, and the combination of NS and FK224 on ovalbumin-induced plasma extravasation

The extravasation of Evans blue dye in the trachea guinea pig trachea after exposure to the aerosolized vehicle of ovalbumin in the presence of phosphoramidon $(2.5 \mathrm{mg} / \mathrm{kg}, i . v$.) was $23.1 \pm$ $4.4 \mathrm{ng} / \mathrm{mg}(\mathrm{n}=5$; Fig. 2). Inhalation of $5 \%$ ovalbumin for $2 \mathrm{~min}$ in the presence of phosphoramidon $(2.5 \mathrm{mg} / \mathrm{kg}$ i.v.) significantly increased the extravasation of the Evans blue dye in the trachea (119.5 $\pm 10.0 \mathrm{ng} / \mathrm{mg}, \mathrm{n}=5 ;$ Fig. 2$)$. Pretreatment with DSCG $(10 \mathrm{mg} / \mathrm{kg}$ i.v. $) 5 \mathrm{~min}$ before aerosol challenge significantly reduced the antigen-induced plasma extavasation in the trachea $(90.0 \pm 6.17 \mathrm{ng} / \mathrm{mg}, \mathrm{n}=5$; Fig. 2$)$. Pretreat- 


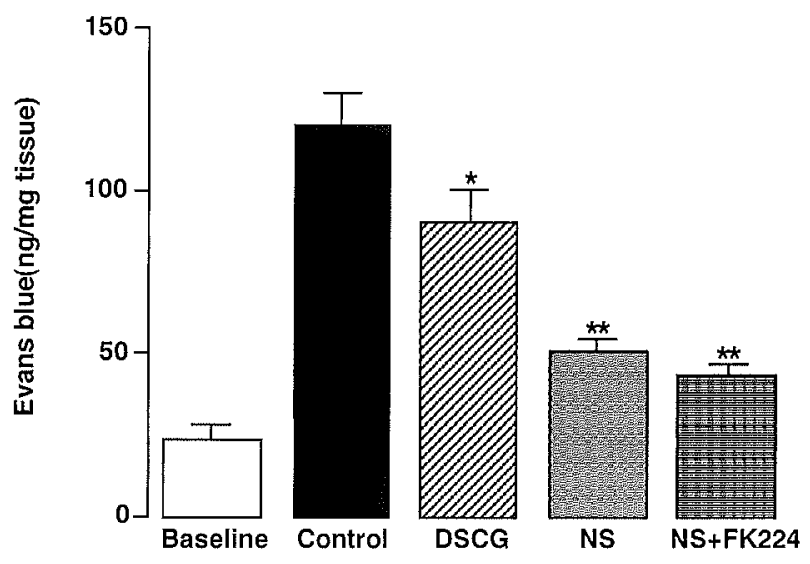

Fig. 2 Effect of nedocromil sodium (NS; $10 \mathrm{mg} / \mathrm{kg}$ $i . v$ ), disodium cromoglycate (DSCG; $10 \mathrm{mg} / \mathrm{kg} i . v$ ) or the combination of $\mathrm{NS}(10 \mathrm{mg} / \mathrm{kg} i . v)$ and $\mathrm{NK}_{1}$ and $\mathrm{NK}_{2}$ receptor antagonist FK224 (3.2 mg/kg i.v.) on Evans blue extravasation in guinea pig trachea induced by inhalation of ovalbumin (OVA; $5 \%$ for 2 $\mathrm{min})$ in presence of phosphoramidon $(2.5 \mathrm{mg} / \mathrm{kg} i .1$., $5 \mathrm{~min}$ before exposure). Plasma extravasation was evaluated by measuring the amount of Evans blue dye extravasated in the trachea after $10 \mathrm{~min}$. Values are means \pm S.E.M; $\mathrm{n}=5$ per group. ${ }^{*} P<0.05, * * P<$ 0.01 versus control (Inhalation of OVA in presence of phosphoramidon) in trachea.

ment with NS (10 mg/kg i.v.) $5 \mathrm{~min}$ before aerosol challenge more sharply inhibited the increase of antigen-induced plasma extavasation in the trachea $(50.2 \pm 3.48 \mathrm{ng} / \mathrm{mg}, \mathrm{n}=5$; Fig. 2$)$. The combination of NS (10 mg/kg i.v) and FK224 $\left(\mathrm{NK}_{1}\right.$ and $\mathrm{NK}_{2}$ receptor antagonist; $3.2 \mathrm{mg} / \mathrm{kg} i$. v.) also reduced antigen-induced plasma extavasation in the trachea $(42.6 \pm 3.9 \mathrm{ng} / \mathrm{mg}, \mathrm{n}=5$; Fig. 2 ), but the inhibition was similar to the inhibition by pretreatment with NS alone. The NS, DSCG, and FK224 vehicle did not affect OVAinduced plasma extravasation (data not shown).

Effect of NS, Antihistaminics, and the combination of NS and Antihistaminics on ovalbumininduced plasma extravasation

The extravasation of Evans blue dye in the guinea pig trachea after exposure to aerosolized vehicle of OVA in the presence of phosphoramidon $(2.5$ $\mathrm{mg} / \mathrm{kg}$ i.v.) was $22.0 \pm 3.7 \mathrm{ng} / \mathrm{mg}(\mathrm{n}=5$; Fig. 3$)$. Inhalation of $5 \%$ OVA for $2 \mathrm{~min}$ in the presence of phosphoramidon $(2.5 \mathrm{mg} / \mathrm{kg}$ i.v.) significantly increased the extravasation of the Evans blue dye in the trachea $(121.9 \pm 10.5 \mathrm{ng} / \mathrm{mg}, \mathrm{n}=5$; Fig. 3).

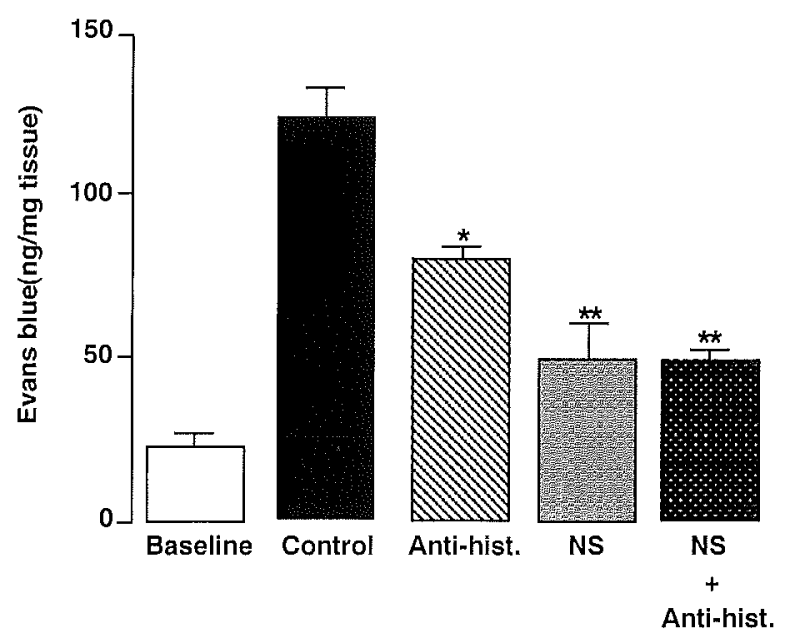

Fig. 3 Effect of nedocromil sodium (NS; $10 \mathrm{mg} / \mathrm{kg}$ i.v.), $\mathrm{H}_{1}$ and $\mathrm{H}_{2}$ receptor antagonists pyrilamine (10 $\mathrm{mg} / \mathrm{kg}$ i.v.) and cimetidine $(10 \mathrm{mg} / \mathrm{kg}$ i.v. $)$ or the combination of NS $(10 \mathrm{mg} / \mathrm{kg} i . v)$ and anti-histamin drug (pyrilamine and cimetidine; $10 \mathrm{mg} / \mathrm{kg} i . \%$. each) on Evans blue extravasation in guinea pig trachea induced by inhalation of ovalbumin ( $5 \%$ for $2 \mathrm{~min}$ ) in presence of phosphoramidon $(2.5 \mathrm{mg} / \mathrm{kg}$ i. . ., 5 min before exposure). Plasma extravasation was evaluated by measuring the amount of Evans blue dye extravasated in the trachea after $10 \mathrm{~min}$. Values are means \pm S.E.M; $\mathrm{n}=5$ per group. ${ }^{*} P<0.05,{ }^{*} P<$ 0.01 versus control (Inhalation of OVA in presence of phosphoramidon) in trachea.

Pretreatment with NS $(10 \mathrm{mg} / \mathrm{kg} \quad$ i.v. $) 5 \mathrm{~min}$ before OVA aerosol challenge inhibited the plasma extravasation in the trachea $(49.4 \pm 4.9$ $\mathrm{ng} / \mathrm{mg}, \mathrm{n}=5$; Fig. 3). Pretreatment with the combination of pyrilamine $(10 \mathrm{mg} / \mathrm{kg}$ i.v. $)$ and cimetidine $(10 \mathrm{mg} / \mathrm{kg}$ i.v.) $30 \mathrm{~min}$ before OVA aerosol challenge also significantly reduced the plasma extravasation, but the inhibition was less prominent as compared with the NS administration. Lastly, pretreatment with the combination of NS $(10 \mathrm{mg} / \mathrm{kg}$ i.v.) and antihistaminic drugs (pyrilamine and cimetidine; $10 \mathrm{mg} / \mathrm{kg}$ i.. . each) $30 \mathrm{~min}$ before OVA aerosol challenge inhibited the extravasation in the trachea $(48.6 \pm 2.9 \mathrm{ng} /$ $\mathrm{mg}, \mathrm{n}=5$; Fig. 3). The inhibition by pretreatment with the combination of NS $(10 \mathrm{mg} / \mathrm{kg} i . v$.) and antihistaminic drugs (pyrilamine and cimetidine; $10 \mathrm{mg} / \mathrm{kg}$ i.v. each) did not differ from the inhibition of antigen-induced plasma extavasation in the trachea by NS alone. The NS, pyrilamine, and cimetidine vehicle had no effect on OVA-induced plasma extravasation (data not shown). 


\section{DISCUSSION}

Bradykinin may be particularly important in activating sensory nerves, and when inhaled by asthma patients, it induces marked dyspnea and coughing, similar to that seen in an asthma attack. Bradykinin is produced from plasma that exudes into the asthmatic airway lumen as a result of plasma extravasation (4). OVA-induced plasma extravasation in sensitized guinea pigs is significantly reduced by the bradykinin $\mathrm{B}_{2}$ receptor antagonist HOE140 (5) or FR173657 (13). The combination of $\mathrm{NK}_{1}$ receptor antagonist CP-96,345 and HOE140 does not potentiate the inhibition produced by CP-96,345 alone (5). These reports suggest that the sensory nerve activation that contributes to antigen-induced plasma extravasation is due to bradykinin release $(5,13)$.

In our experiment, pretreatment with NS $(0.1$, 1 , and $10 \mathrm{mg} / \mathrm{kg}$ i.v.) $5 \mathrm{~min}$ before aerosol challenge significantly and dose-dependently reduced the bradykinin-induced plasma extravasation in the trachea. The inhibition of bradykinin-induced plasma extravasation in the guinea pig trachea by NS (10 mg/kg i.v.) was not significantly different from the baseline, but was significantly greater than the inhibition caused by DSCG $(10 \mathrm{mg} / \mathrm{kg} i$. v.). We further investigated whether NS inhibits plasma extravasation in response to antigen in sensitized guinea pig airway and compared it with DSCG and the combination of NS and the $\mathrm{NK}_{1}$ and $\mathrm{NK}_{2}$ receptor antagonist FK224. The inhibition by pretreatment with NS was also significantly greater than that caused by DSCG. The inhibition of antigen-induced plasma extavasation in the trachea by the combination of $\mathrm{NS}$ and the $\mathrm{NK}_{1}$ and $\mathrm{NK}_{2}$ receptor antagonist FK224 was reduced, but similar to the inhibition by pretreatment with NS alone. FK224 interacts with both $\mathrm{NK}_{1}$ and $\mathrm{NK}_{2}$ receptors and inhibits neurogenic inflammation completely $(11,12)$. These results suggest that NS completely inhibits the neurogenic inflammation activated by bradykinin during antigen-induced plasma extavasation in sensitized guinea pig trachea.

We also investigated whether NS inhibits plasma extravasation in response to antigen in sensitized guinea pig airway and compared it with antihistaminic drugs and the combination of NS and antihistaminic drugs. Some reports describe inhibition of antigen-induced plasma extravasation by NS alone or by antihistaminic drugs alone, but not by a combination of NS and antihiataminic drugs $(2,7)$. In the present study, pretreatment with pyrilamine and cimetidine blocked only part of histamine significantly reduced the plasma extravasation in the trachea. Pretreatment with the combination of NS and antihistaminic drugs (pyrilamine and cimetidine) inhibited the extravasation in the trachea more than the antihistaminic drugs alone. However, the inhibition of antigen-induced plasma extavasation in the trachea by NS alone did not differ from the inhibition by pretreatment with the combination of NS and antihistaminic drugs. However, it has been reported that NS does not reduce histamine-induced plasma extravasation (2). Our findings suggest that NS inhibits antigeninduced plasma extravasation by reducing histamine release from inflammatory cells, not by blocking histamine receptors.

NS has been shown to be capable of inhibiting chloride ion flux in mast cells, epithelial cells, and neurons, and this action may explain how it prevents responses such as mast-cell degranulation, the effects of osmolarity challenges in the airways, and neuronal activation(1). NS was found to be at least one order of magnitude more potent than DSCG in suppressing histamine release from mast cells (9). Since NS alone had only a small effect on extravasation induced directly by histamine and PAF, its effect is probably due to inhibition of mediator release from inflammatory cells (presumably mast cells)(2). NS may have effects on sensory nerve endings, which may be an important site of action in the reduction of both neurogenic inflammation in the airways and the symptoms of asthma, including cough (2). We have shown that NS significantly reduces antigen-induced plasma extravasation in guinea pig airways. NS inhibits neurogenic inflammation activated by bradykinin, and its inhibitory effect is more potent than that of DSCG. These findings suggest that NS suppresses the histamin release from mast cell and the release of tachykinin from activated sensory nerves in response to bradykinin stimulation (Fig. 4).

If these findings are substantiated in humans, NS may prove to be a useful therapeutic agent compared with DSCG for the treatment of inflammatory disease such as asthma.

\section{REFERENCES}

1. Alton E. W. F. W., Norris A. A. (1996) Chloride transport and the actions of nedocromil sodium and cromolyn sodium in asthma. J. Allergy Clin. Inmunol. 98, S102- 


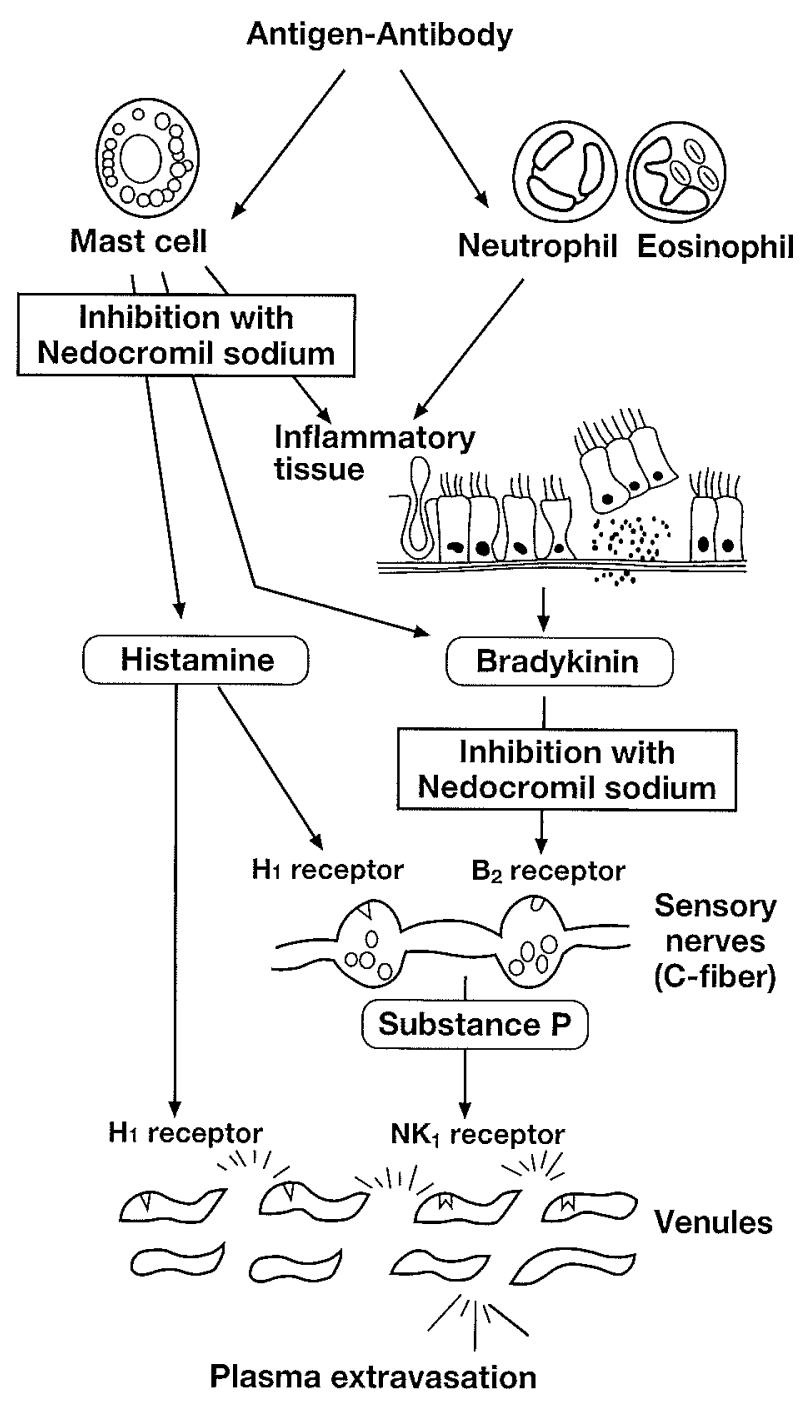

Fig. 4 Schematic representation of antiinflammatory action by nedocromil sodium (NS) in airway

S106.

2. Barnes P. J. (1989) Effect of nedocromil sodium on airway microvascular leakage and neural reflexes. Drugs 37, 94100.

3. Barnes P. J., Boschetto P., Rogers D. F., Belvisi M., Roberts N., Chung K. F., Evans T. W. (1990) Effects of treatment on airway microvascular leakage. Eur. Respir. J.
3, $5663-S 671$.

4. Barnes P. J. (1996) Neuroeffector mechanisms: The interface between inflammation and neuronal responses. $J$. Allergy Clin. Immunol. 98, S73-S83.

5. Bertrand C., Nadel J.A., Yamawaki I., Geppetti P. (1993) Role of kinins in the vasucular extravasation evoked by antigen and mediated by tachykinins in guinea pig trachea. J. Inmunol. 151, 4902-4907.

6. Calonge M., Montero J. A., Herreras J. M., Juberias J. R., Pastor J. C. (1996) Efficacy of nedocromil sodium and cromolyn sodium in an experimental model of ocular allergy. Ann. Allergy Asthma Immunol. 77, 124-130.

7. Evans T. W., Rogers D. F., Aursudkij B., Chung K. F., Barnes P. J. (1988) Inflammatory mediators involved in antigen-induced airway microvascular leakage in guinea pigs. Am. Rev. Respir. Dis. 138, 395-399.

8. Javdan P., Figini M., Emanueli C., Geppetti P. (1995) Nedocromil sodiium reduces allergen-induced plasma extravasation in the guinea pig nasal mucosa by inhibition of tachykinin release. Allergy 50, 825-829.

9. Leung K. B. P., Flint K. C., Brostoff J., Hundspith B. N., Johnson N. M., Lau H. Y. A., Liu W. L., Pearce F. L. (1988) Effect of sodium cromoglycate and nedocromil sodium on histamine secretion from human lung mast cells. Thorax 43, 756-761.

10. Laitinen L. A., Heino M., Laitinen A., Kava T., Haahtela T. (1985) Damage of the airway epithelium and bronchial reactivity in patients with asthma. Am. Rev. Respir. Dis. 131, 599-606.

11. Morimoto H., Murai M., Maeda Y., Yamaoka M., Nishikawa M., Kiyotoh S., Fujii T. (1992) FK224, a novel cyclopeptide substance $\mathrm{P}$ antagonist with $\mathrm{NK}_{1}$ and $\mathrm{NK}_{2}$ receptor selectivity. J. Pharmacol. Exp. Ther. 262, 398402.

12. Murai M., Morimoto H., Maeda Y., Kiyotoh S., Nishikawa M., Fujii T. (1992) Effect of FK224, a Novel Compound $\mathrm{NK}_{1}$ and $\mathrm{NK}_{2}$ Receptor antagonist, on airway constriction and airway edema induced by neurokinins and sensory nerve stimulation in guinea pigs. J. Pharmacol. Exp. Ther. 262, 403-408.

13. Watanabe M., Yoshihara S., Abe T., Oyama M., Arisaka O. (1999) Effects of the orally active non-peptide bradykinin $\mathrm{B}_{2}$ receptor antagonist, on plasma extravasation in guinea pig airways. Eur. J. Pharmacol. 367, 373-378.

14. Yoshihara S., Geppetti P., Lindén A., Hara M., Chan B., Nadel J. A. (1996) Tachykinins mediate the potentiation of antigen-induced bronchoconstriction by cold air in guinea pigs. J. Allergy Clin. Immunol. 97, 756-760.

15. Yoshihara S., Nadel J. A., Figini M., Emanueli C., Pradelles P., Geppetti P. (1998) Endogenous nitric oxide inhibits bronchoconstriction induced by cold-air inhalation in guinea pigs - Role of kinins-. Am. J. Respir. Crit. Care Med. 157, 547-552. 